\title{
ANAL YSIS OF THE SOLAR STILL PRODUCTIVITY BY SIMILITUDE APPLICATIONS
}

\author{
*Ghanem T.H.
}

\begin{abstract}
The aim of the present study is to develop mathematical analysis for common design solar still involving all ambient surrounding variables affecting its productivity and coefficient of performance. Two similar units of the solar stills were used namely: Control unit and cooled glass cover unit (cooled unit). The prediction equations for the productivity of the two studied units were reasonably accepted with coefficients of determinations ranged between $98-99 \%$.

It was also found that the cooled unit has highest values of the productivity and coefficient of performance. The daily productivity and average coefficient of performance were $6.1655 \mathrm{~kg} / \mathrm{m}^{2}, 59.52 \%$ for the cooled unit compared to $5.536 \mathrm{~kg} / \mathrm{m}^{2}$ and $52.19 \%$ for the control unit.
\end{abstract}

\section{INTRODUCTION}

$\mathrm{F}$ Trich and Sommerfeld (1973) designed a wick-type collector evaporator or distiller of a shallow depth. They reported that it has a production rate of $3.8-4.4 \mathrm{~L} / \mathrm{m}^{2}$.day, with an operational efficiency of about 40 to $46 \%$. Mostafa et. et. al. (1994) mentioned that the productivity of solar stills reaches its maximum value at an optimum cover slope. They added that the slope depends on the time of the year, the location of still, and the ambient conditions. An average slope of 20 to 25 degrees from the horizontal shows satisfactory results for a wide range of stills. Ernani (1996) studied a solar still versus solar evaporator. He concluded that, the distillation rate increases with increasing water temperature and temperature differences. Zabady (1997) mentioned that the total daily productivity decreases from 4646 to 4506,4416 and 4323 $\mathrm{cm}^{3} / \mathrm{m}^{2}$.day with brine depth increased from 0.5 to $1.0,1.5$ and $2 \mathrm{~cm}$ respectively. The nocturnal production increased from 835 to 850,900 and $912 \mathrm{~cm}^{3} / \mathrm{m}^{2}$ when brine depth increased from 0.5 to $1.0,1.5$ and $2 \mathrm{~cm}$ respectively. Abdel-Rahman (2009) reported that at a maximum recorded

\footnotetext{
*Associate Prof., Agric. Eng.. Fac. of Agric., Al-Azhar Univ.
}

Misr J. Ag. Eng., January 2010 
value of solar intensity $825 \mathrm{w} / \mathrm{m}^{2}$, and the corresponding air temperature of $40.7{ }^{\circ} \mathrm{C}$, the maximum and minimum solar still productivity and the corresponding transpiration rate accomplished in September were 3196, $1910 \mathrm{~g} / \mathrm{m}^{2}$ and 2234, $1254 \mathrm{~g} / \mathrm{m}^{2}$ respectively. Tayel et. al. (2009) designed and evaluated four different units of solar stills namely: control unit, preheated unit, air blowing unit and air suction unit. They studied several parameters affecting the productivity of the solar still as: brine depth, slope angle of glass cover, feeding water and covering materials. They reported that the preheating unit has the highest productivity $\left(6030 \mathrm{~cm}^{3} / \mathrm{m}^{2}\right.$. day) with brine depth of $0.02 \mathrm{~m}$, slope angle of $20^{\circ}$.

\section{THEORITICAL APPROACH}

The first step in the similitude application is to define the most associated variables affecting the phenomena under investigation. The following are the pertinent and independent variables considered to affect the productivity of the solar still. Their units and dimensions are as follows:

\begin{tabular}{|c|c|l|c|c|}
\hline NO. & Symbol & \multicolumn{1}{|c|}{ Description } & Dimension & Units \\
\hline 1 & $\mathrm{D}$ & \multicolumn{1}{|c|}{ Productivity of the solar still } & $\mathrm{M} \mathrm{L}^{-2} \mathrm{t}^{-1}$ & $\mathrm{~kg} / \mathrm{m}^{2} . \mathrm{h}$ \\
\hline 2 & $\Delta \mathrm{P}$ & $\begin{array}{l}\text { Evaporation and condensation } \\
\text { potential or the difference } \\
\text { between partial pressure at } \\
\text { glass cover temperature and } \\
\text { water temperatur }\end{array}$ & $\mathrm{M} \mathrm{L}^{-1} \mathrm{t}^{-2}$ & $\mathrm{~kg} \mathrm{~m}{ }^{-1} \mathrm{~s}^{-2}$ \\
\hline 3 & $\mathrm{I}_{\mathrm{p}}$ & Solar intesity & $\mathrm{HL}^{-2} \mathrm{t}^{-1}$ & $\mathrm{~W} / \mathrm{m}^{2}$ \\
\hline 4 & $\mathrm{Q}_{\mathrm{ec}}$ & $\begin{array}{l}\text { Heat utilized in vaporizing } \\
\text { water in the still }\end{array}$ & $\mathrm{HL}^{-2} \mathrm{t}^{-1}$ & $\mathrm{~W} / \mathrm{m}^{2}$ \\
\hline 5 & $\Delta \mathrm{T}_{\mathrm{g}-\mathrm{a}}$ & $\begin{array}{l}\text { Temperature difference } \\
\text { between glass cover and the } \\
\text { ambient air. }\end{array}$ & $\theta$ & ${ }^{\mathrm{o}} \mathrm{K}$ \\
\hline 6 & $\mathrm{U}_{\mathrm{L}}$ & Over all heat loss coefficient & $\mathrm{HL}^{-2} \mathrm{t}^{-1} \theta-{ }^{1}$ & $\mathrm{~W} / \mathrm{m}^{2}{ }^{2} \mathrm{~K}$ \\
\hline 7 & $\lambda$ & Brine depth & $\mathrm{L}$ & $\mathrm{m}$ \\
\hline 8 & $\phi$ & Elapsed time & $\mathrm{t}$ & $\mathrm{h}$ \\
\hline 9 & Cos $\beta$ & Glass cover tilt angle & \multicolumn{2}{c|}{} \\
\hline
\end{tabular}

The general relationship for the productivity of the solar still as a function of the associated independent variables can be expressed as: Misr J. Ag. Eng., January 2010 
$\mathrm{D}=\mathrm{F}\left(\Delta \mathrm{P}, \mathrm{I}_{\mathrm{p}}, \mathrm{Q}_{\mathrm{ec}}, \Delta \mathrm{T}, \mathrm{U}_{\mathrm{L}}, \lambda, \phi, \operatorname{Cos} \beta\right)$

According to the Buckingham Pi-theorem, the number of dimensionless and independent quantities required to express a relationship among the variables in any phenomenon is equal to the number of quantities involved, minus the number of dimensions of those quantities Murphy (1950). In the present study nine quantities with five dimensions is involved. So, four dimensionless groups can be formed. The dimensional analysis yields the following relationship for both tested units:

$$
\frac{\lambda D}{\Phi \Delta p(3600)^{2}}=\left[A\left(\frac{Q_{e c}}{I_{p}}\right)+C\right] \cos \beta
$$

Where $\mathrm{A}$ and $\mathrm{C}$ are functions of $\pi 3$. The value $(3600)^{2}$ is used as conversion factor of $\Delta \mathrm{p}$ to $\mathrm{kg} \mathrm{m}^{-1} \mathrm{~h}^{-2}$.It is notable that $\pi 2$ represents the C.O.P of the solar still. $\pi_{3}=\left[\mathrm{U}_{\mathrm{L}} \Delta \mathrm{T}_{\mathrm{g}-\mathrm{a}} / \mathrm{I}_{\mathrm{P}}\right]$ represents the ratio between heat losses and solar insolation. $\pi_{1}$ includes $\Delta \mathrm{p}$ that represents the potential of evaporation and condensation. $\pi 4$ is a constant represents the view factor of sky, ground and surrounding with respect to cover tilt angle.

\section{MATERIALS AND METHODS}

In the present study two similar solar stills were used . The experimental part was carried out on the roof of the Agricultural Engineering Department Faculty of Agriculture Al-Azhar University Nacr City .

\section{Solar still construction:}

The solar still as shown in Fig.(1) is consists of an evaporator of four sides of galvanized iron sheet of $0.6 \mathrm{~mm}$ thick .The basin dimensions (evaporator) are $865 \times 695 \mathrm{~mm}$, the still was insulated from its bottom and sides by two layers $0.03 \mathrm{~m}$ fpolyurethane and $0.016 \mathrm{~m}$ wood panels. The space above the basin is completely enclosed by a transparent cover tightly. The inside still base and sides are painted twice with a black paint. The outer surface of the glass cover for the cooled unit is surrounded by three sides of glass slices $30 \mathrm{~mm}$ high, two ducts at the ends of the glass cover was made to allow cooling water to be easily collected and recycled. Saline water was distillated by the solar still and water was continuously fed.

Misr J. Ag. Eng., January 2010 


\section{Measuring instrumentations:}

1 Thermocouples :Temperature were measured using type-K

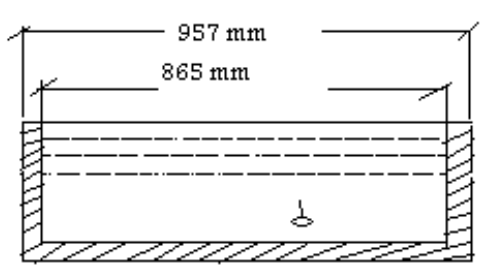

Elevation

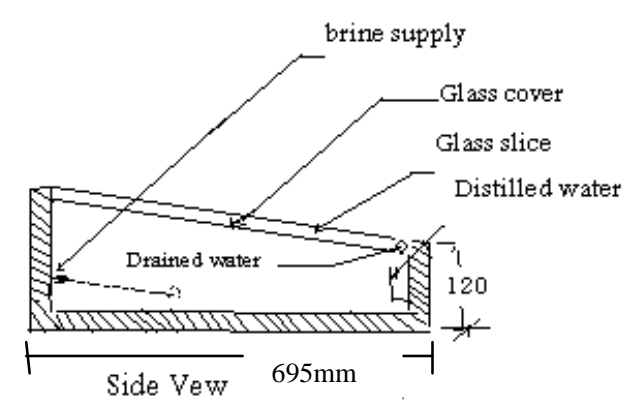

Side Vew

Fig.(1) Construction of the solar still (CGC unit)

thermocouples, the output device includes a large 4-digits temperature reading display and electronic circuitry, the specifications of thermocouples are manufactured inU.S.A, model 8528-40, full accuracy $18-28^{\circ} \mathrm{C}$ and useful range $4-45^{\circ} \mathrm{C}$

2 Graduated glass bottle :(1 litter) was used to measure the amount of distilled water.

3 Solar intensity device: A black and white pyranometer was constructed and tested by Ghanem (1989) and calibrated in the solar energy department, National research center, Giza Egypt.It was used for measuring the solar intensity in $\mathrm{W} / \mathrm{m}^{2}$.

4 Turbo meter: A turbo meter was used for measuring the wind speed in $\mathrm{m} / \mathrm{s}$, the meter is manufactured in U.S.A of measuring rang: $0-44.8$ $\mathrm{m} / \mathrm{s}$.

\section{METHODS}

\section{Solar still energy balance}

In the present work assuming steady state, the performance of the solar still can be described by energy balance that indicates conversion of the solar energy into useful energy gain, thermal losses and optical losses. The useful energy used in evaporation and condensation" $\mathbf{Q}_{\mathbf{e c}}$ " is equal to the difference between absorbed energy " $\mathbf{Q}_{\text {abs. }}$ "and energy losses. The thermal energy lost from the still to the surrounding by conduction, convection and infrared-radiation can be presented by the over-all heat 
transfer coefficient " $\mathbf{U}_{\mathbf{L}}$ " times difference of the average value of water and steel temperature" $\mathbf{T}_{\mathbf{w s}}$ " and the ambient air temperature " $\mathbf{T}_{\mathbf{a}}{ }^{\prime}$. :

$$
\mathbf{Q}_{\mathrm{ec}}=\mathbf{Q}_{\mathrm{abs}} \cdot-\mathbf{U}_{\mathrm{L}}\left(\mathbf{T}_{\mathrm{ws}}-\mathbf{T}_{\mathrm{a}}\right)
$$

\section{Over-all heat transfer coefficient of the solar still}

It is useful to develop the concept of over-all heat loss coefficient for the solar still to simplify the calculations. A thermal net work Fig.(2) was made to change the thermal loss in a similar electrical resistance around the basin to help in estimating the overall heat loss coefficient and the useful energy gain. Fig.(3) shows the equivalent thermal net work for the solar still. This method is considered the simplest one to evaluate the over-all heat loss coefficient for flat plate collectors as reported by Ria (1980) and applied by Shoukr et. al.(1986). The over-all heat transfer coefficient is the sum of top" $\mathbf{U}_{\mathbf{T}}$ ", back " $\mathbf{U}_{\mathbf{b}}$ "and edge " $\mathbf{U}_{\mathbf{E}}$ "losses respectively which can be represented as:

$$
\mathbf{U}_{\mathbf{L}=\mathbf{U}_{\mathbf{T}}}+\mathbf{U}_{\mathbf{b}}+\mathbf{U}_{\mathbf{E}}
$$

\section{2-1 Top loss coefficient $U_{T}$}

Energy losses through the top of the still is essentially a result of convection and radiation between the basin, cover plate, radiation and convection due to ambient air and sky temperatures.

\section{2-1-1 Basin loss coefficient $R_{1}$}

The convection heat losses can be evaluated according to Rai(1980) as follows:

$$
\begin{aligned}
& h c_{w-g}=8.84 \times 10^{-4}\left(\left(T_{w}-T_{g}\right)+\left(\frac{P_{w}-P_{w g}}{265 \times 10^{3}-P_{w}}\right)\left(T_{w}+273\right)\right)^{1 / 3}\left(P_{w}-P_{w g}\right) \\
& h \mathbf{r}_{\mathbf{w}-\mathrm{g}}=\frac{0.9 \sigma\left(\mathbf{T}_{\mathbf{w}}{ }^{4}-\mathbf{T}_{\mathbf{g}}{ }^{4}\right)}{\mathbf{T}_{\mathbf{w}}-\mathbf{T}_{\mathrm{g}}}
\end{aligned}
$$

Where

$\mathrm{hc} \mathrm{w}_{\mathrm{w}} \mathrm{g}$ is the convection heat transfer coefficient between glass cover and brine water; $\mathrm{W} / \mathrm{m}^{2}{ }^{\circ} \mathrm{K}$,

$\mathrm{hr}_{\mathrm{w}-\mathrm{g}}$ : is the radiation heat transfer coefficient between glass cover and brine water; $\mathrm{W} / \mathrm{m}^{20} \mathrm{~K}$,

Misr J. Ag. Eng., January 2010 
PROCESS ENGINEERING

$\mathrm{T}_{\mathrm{w}}$ : is brine water temperature; ${ }^{\mathrm{o}} \mathrm{K}$,

$\mathrm{T}_{\mathrm{g}}$ : is the glass cover temperature ${ }^{\circ} \mathrm{K}$;

$\mathrm{P}_{\mathrm{w}}$ : is the partial pressure of water in $\mathrm{P}_{\mathrm{a}}$ at $\mathrm{T}_{\mathrm{w}}{ }^{\circ} \mathrm{C}$, .

$\mathrm{P}_{\mathrm{wg}}$ : is the partial pressure of water in $\mathrm{P}_{\mathrm{a}}$ at $\mathrm{T}_{\mathrm{g}}{ }^{\circ} \mathrm{C}$,

$\sigma$ : is Stefan Boltzman $56.7 \times 10^{-9} \mathrm{~W} / \mathrm{m}^{2}{ }^{\circ} \mathrm{K}{ }^{4}$.

Both partial pressures are evaluated by regressing steam table data for the partial pressure as a function of temperature at a range of $20-75{ }^{\circ} \mathrm{C}$ for the present study as follows:

$$
\mathrm{P}=\mathbf{0 . 1 4 8 3} \mathrm{T}^{3}-\mathbf{8 . 4 0 8 1} \mathrm{T}^{2}+\text { 341.34T }- \text { 2323.3 } \quad\left(\mathrm{R}^{2}=1\right)
$$

Then, the loss resistance from the basin to the glass cover will be:

$$
\mathbf{R}_{1}=\frac{1}{\left(h_{\mathbf{w}-\mathbf{g}}+\mathbf{h r} \mathbf{r}_{\mathbf{w}-\mathrm{g}}\right)}
$$

\section{2-1-2 Glass cover loss to surrounding $\mathbf{R}_{\mathbf{2}}$}

The resistance from the glass cover to surrounding due to the wind blowing and radiation "hr $\mathbf{g}_{\text {-a" }} \mathrm{W} / \mathrm{m}^{2}{ }^{\mathrm{o}} \mathrm{K}$ can be determined according to Duffie and Bechman(1980) as follows:

$$
\mathrm{hr}_{\mathrm{g}-\mathrm{a}}=\varepsilon_{\mathrm{c}} \sigma\left(\mathrm{T}_{\mathrm{g}}^{2}+\mathrm{T}_{\mathrm{a}}^{2}\right)\left(\mathrm{T}_{\mathrm{g}}+\mathrm{T}_{\mathrm{s}}\right)
$$

Where :

$\varepsilon_{\mathrm{g}}:$ is the emittance of the glass cover; 0.9 ,

$\mathrm{T}_{\mathrm{s}}$ : is the sky absolute temperature ${ }^{\circ} \mathrm{K}$,

$\mathrm{T}_{\mathrm{a}}$ : is the ambient air temperature, ${ }^{\circ} \mathrm{K}$,

The wind losses " $h_{w}{ }$ W $/ \mathrm{m}^{2}{ }^{\circ} \mathrm{K}$ can be evaluated according to Rai(1980) :

$$
\begin{gathered}
\mathrm{h}_{\mathrm{w}}=5.7+3.8 \mathrm{~V}_{\mathrm{w}} \ldots \\
\mathrm{T}_{\mathrm{s}}=0.0552 \mathrm{~T}_{\mathrm{a}}^{1.5} .
\end{gathered}
$$

Then the top loss coefficient is:

$$
U_{T}=\frac{1}{R_{1}+R_{2}}=\left[\frac{1}{\left(h c_{w-g}+h r_{w-g}\right)}+\frac{1}{\left(h_{g-a}+h_{w}\right)}\right]^{-1}
$$

\section{2-2 Back loss coefficient $U_{b}$}

The resistance to heat flow through the bottom of the steel pate is " $\mathbf{R}_{\mathbf{3}}$ " which is covered by insulation can be determined as follows:

Misr J. Ag. Eng., January 2010 


$$
\mathbf{R}_{\mathbf{3}}=\mathbf{L}_{\mathrm{s}} / \mathbf{k}_{\mathrm{s}}
$$

Where " $\mathbf{L}_{\mathbf{s}}=0.0006 \mathrm{~m}$ " is the thickness of the steel sheet constructing the basin and " $\mathbf{k}_{\mathbf{s}}=48 \mathrm{~W} / \mathrm{m}^{.0} \mathrm{~K}$ " is the thermal conductivity of that sheet.

Duffie and Beckman (1980) reported that the bottom resistance is due to insulation.

\section{2-3 Resistance due to insulation}

The energy losses through the bottom of the solar still is represented by three resistances " $\mathbf{R}_{\mathbf{4}}$ ", "R $\mathbf{R}_{\mathbf{5}}$ "and " $\mathbf{R}_{\mathbf{6}}$ ". $\mathbf{R}_{\mathbf{4}}$ and $\mathbf{R}_{\mathbf{5}}$ are resistances due to insulation and $\mathbf{R}_{\mathbf{6}}$ is due to convection and radiation to the environment. Since $\mathbf{R}_{\mathbf{4}}$ and $\mathbf{R}_{\mathbf{5}} \quad \gg, \mathbf{R}_{\mathbf{6}}$ we may neglect $\mathbf{R}_{\mathbf{6}}$ in calculations of the bottom loss coefficient as reported by Rai(1980). So, back loss coefficient " $\mathbf{U}_{\mathbf{b}}$ " for the two layers of insulation, polyurethane and plywood of thickness and thermal conductivity of $0.03 \mathrm{~m}$, $0.0245 \mathrm{~W} / \mathrm{m}^{.0} \mathrm{~K}$ and $0.016 \mathrm{~m}, 0.12$ $\mathrm{W} / \mathrm{m}^{\circ} \mathrm{K}$ respectively, can be determined as follows:

$$
\mathrm{U}_{\mathrm{b}}=\frac{1}{\mathrm{R}_{\mathrm{b}}}=\frac{1}{\left(\mathrm{~L}_{1} / \mathrm{K}_{1}\right)+\left(\mathrm{L}_{2} / \mathrm{K}_{2}\right)}
$$

\section{2-4 Edge loss coefficient $U_{E}$}

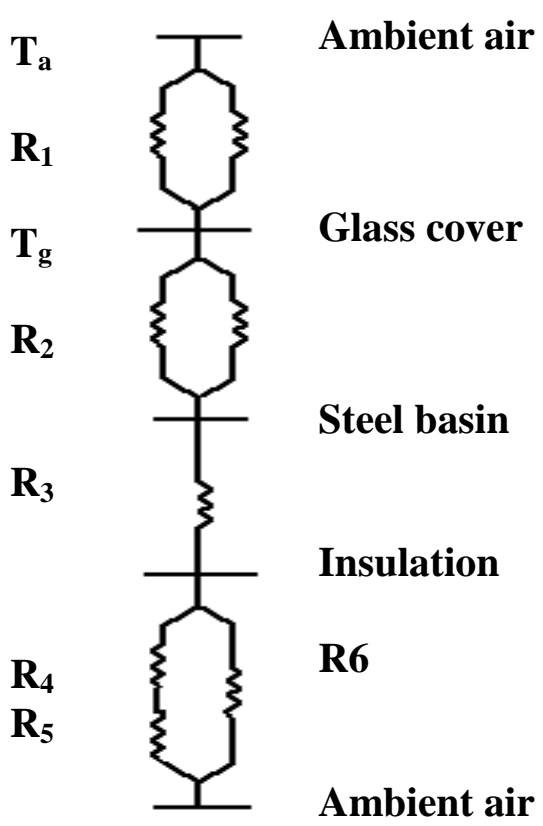

Fig.(2) Thermal net work of the still.

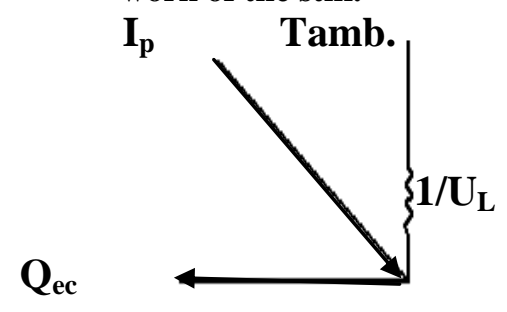

Fig.(3) Equivalent network.

Rai (1980) reported that if the edge

insulation thickness is kept equal to the bottom insulation thickness, the edge losses may be estimated by assuming one dimensional sideway heat flow around perimeter of the still. Shoukr et.al.(1986) mentioned that the evaluation of edge losses is very complicated .However, in well designed system, the edge losses should be small that it is not necessary to predict it with great accuracy.

$\mathbf{U}_{\mathbf{E}}=(\mathbf{U} \mathbf{A})$ edge/ $\mathbf{A}_{\mathbf{s}}$

Misr J. Ag. Eng., January 2010 
Where ( $\mathbf{U}$ A) edge is edge loss coefficient multiplied by its area $\mathrm{m}^{2}$ and $\mathrm{A}_{\mathrm{s}}$ is the solar still area $\mathrm{m}^{2}$.

\section{Evaluation of heat flux by evaporation}

The rate of heat flux due to vaporizing water within the solar still"Qec $\mathrm{W} / \mathrm{m}^{2}$ "can be determined according to Mostafa et.al. (1994) as follows:

$$
Q_{e c}=0.0061\left[\left(T_{w}-T_{g}\right)+\left(\frac{P_{w}-P_{w g}}{265 \times 10^{3}-P_{w}}\right)\left(T_{w}+273\right)\right]^{1 / 3}\left(P_{w}-P_{w g}\right) L_{H V}
$$

Where $\mathrm{L}_{\mathrm{Hv}}$ is the latent heat of vaporization of water $\mathrm{kJ} / \mathrm{kg}$ which can be evaluated by regressing steam table data for the latent heat of vaporization as a function of temperatures within the range of $20-75{ }^{\circ} \mathrm{C}$ in the present study as follows:

$$
\mathbf{L}_{\mathrm{HV}}=\mathbf{- 2 . 4 1 2 4 \mathrm { T } + \mathbf { 2 5 0 2 . 9 }}
$$

To study the effect of glass cover temperature on the productivity and coefficient of performance of the solar still, two similar solar stills were constructed. One of them was used as a control unit and the other was cooled by spraying water three times per hour on the upper surface of the glass cover to reduce its temperature. Brine depth of $0.02 \mathrm{~m}$ and $20^{\circ}$ tilt angle of the glass cover were used as reported by Tayel et. al.(2009). Solar intensity, ambient air, glass cover, steel basin, water in the tank and cooling water temperatures were hourly recorded. Wind speed was continuously recorded and average values were used.

\section{RESULTS AND DISCUSSIONS}

\section{3-1 Prediction equations :}

In the present study Table (1) and (2) summarize calculations for and $\pi 3$ for the cooled glass cover and control units. Figs.(4)and (5) showed justified relations between $\pi$ land $\pi 2$ at constant tilt angle of the glass cover i.e $\cos \alpha=0.9397$, constant brine depth $\mathrm{L}=0.02 \mathrm{~m}$ and elapsed time of one hour, for the cooled cover and control unit of the form:

$$
\frac{\lambda \mathbf{D}}{\mathbf{\Phi} \mathbf{P}}=\left[\mathrm{A}\left(\frac{\mathbf{Q}_{\mathbf{e c}}}{\mathbf{I} \mathbf{p}}\right)+\mathbf{C}\right] \cos \boldsymbol{\beta}
$$

Where $A$ and $C$ parameters are functions of $\pi_{3}=\left[\mathrm{U}_{\mathrm{L}} \Delta \mathrm{T}_{\mathrm{g}-\mathrm{a}} / \mathrm{I}_{\mathrm{P}}\right]$, Figs (6) shows the best fit relations, which are for the cooled unit:

$$
\begin{array}{ll}
\mathrm{A}=2.01 \times 10^{-14} \pi_{3}+4.475 \times 10^{-15} & \left(\mathrm{R}^{2}=0.8\right) . . \\
\mathrm{C}=4.63 \times 10^{-12} \pi_{3}+6.17 \times 10^{-14} & \left(\mathrm{R}^{2}=0.98\right)
\end{array}
$$

Misr J. Ag. Eng., January 2010 
And for the control unit :

$$
\begin{array}{cl}
A=-7.72 \times 10^{-15} \pi_{3}+1.39 \times 10^{-13} & \left(\mathrm{R}^{2}=0.85\right) \\
\mathrm{C}=1.54 \times 10-12 \pi_{3}+1.543 \times 10^{-16} & \left(\mathrm{R}^{2}=95\right) \ldots
\end{array}
$$

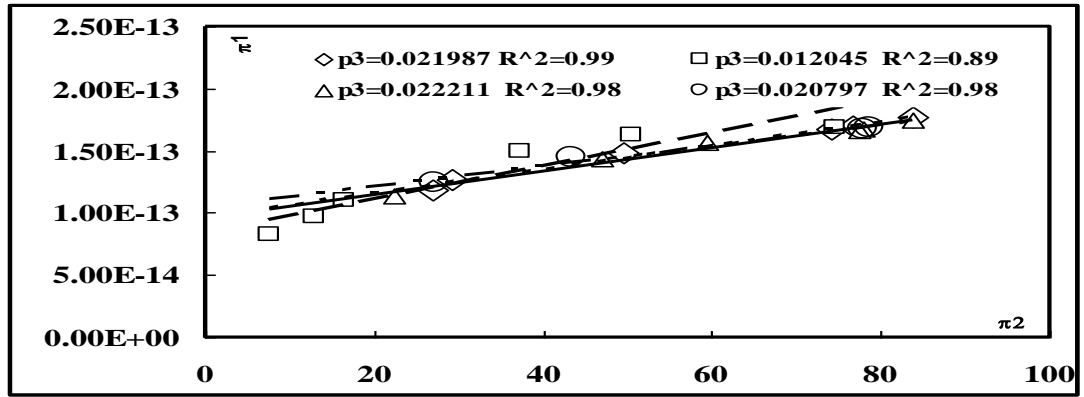

Fig.(4)Effect of $\pi 2$ on $\pi 1$ for the cooled unit.

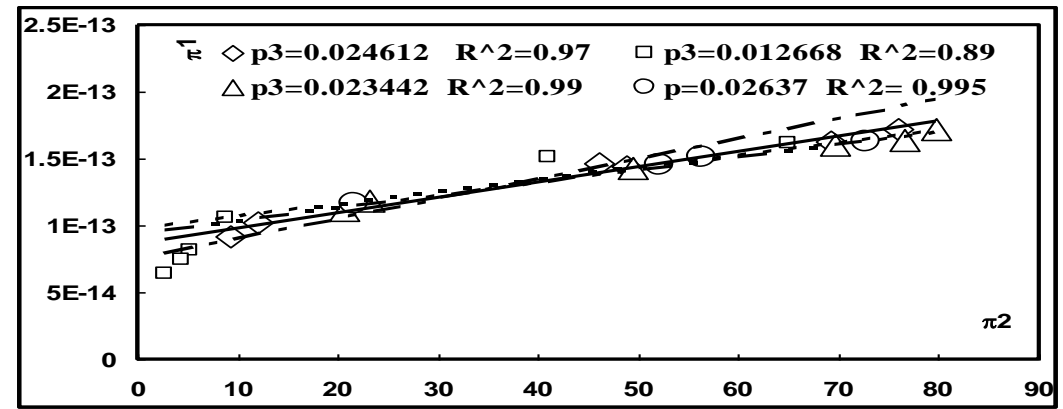

Fig.(5) Effect of $\pi 2$ on $\pi 1$ for the control unit.
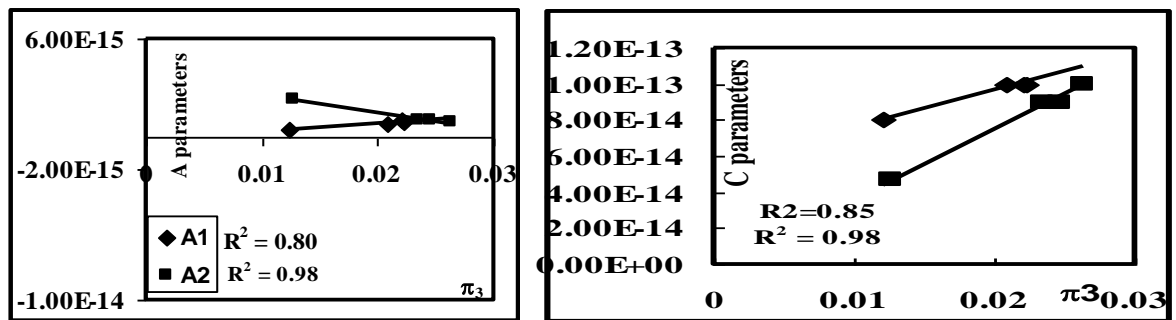

Fig (6)Evaluation of $\mathrm{A}$ and $\mathrm{C}$ parameters of the two studied units.

\section{3-2 Productivity of the solar still}

Prediction equation for determining the productivity of the cooled cover unit can be presented as follows:

$$
D=\left[1.3 \times 10^{-5}\left(\frac{Q_{e c}}{I_{p}}\right)\left(\frac{U_{L} \Delta T_{g-a}}{I_{p}}\right)+0.003\left(\frac{U_{L} \Delta T_{g-a}}{I_{p}}\right)+2.9 \times 10^{-6}\left(\frac{Q_{e c}}{I_{p}}\right)+4 \times 10^{-4}\right] \Delta p
$$

And for the control unit:

$$
D=\left[-5 \times 10^{-5}\left(\frac{Q_{e c}}{I_{p}}\right)\left(\frac{U_{L} \Delta T_{g-a}}{I_{p}}\right)+10^{-3}\left(\frac{U_{L} \Delta T_{g-a}}{I_{p}}\right)+9 \times 10^{-5}\left(\frac{Q_{e c}}{I_{p}}\right)+10^{-7}\right] \Delta p
$$

Misr J. Ag. Eng., January 2010 
Table (1) Evaluation of $\pi 1, \pi 2$ and $\pi 3$ for the cooled glass cover unit.

\begin{tabular}{|c|c|c|c|c|c|c|c|}
\hline $\mathbf{I}_{\mathbf{P}}$ & $\Delta \mathbf{T}_{\mathrm{g}-\mathrm{a}}$ & $\mathbf{Q}_{\mathrm{ec}}$ & $\Delta \mathbf{P}_{\mathrm{w}-\mathrm{g}}$ & $\mathbf{U}_{\mathbf{L}}$ & $\pi 1$ & $\pi 2$ & $\pi 3$ \\
\hline $\begin{array}{l}\text { W/ } \\
\mathbf{m}^{2}\end{array}$ & ${ }^{\mathbf{0}} \mathbf{K}$ & $\begin{array}{l}\text { W/ } \\
\mathbf{m}^{2}\end{array}$ & $\mathbf{P}_{a}$ & $\mathrm{~W} / \mathrm{m}^{2}{ }^{0}{ }^{0} \mathrm{~K}$ & $\lambda \mathrm{D} / \Delta \mathrm{p} \phi$ & $\begin{array}{c}\mathbf{Q}_{\mathrm{ed}} / \mathbf{I}_{\mathbf{P}} \\
\%\end{array}$ & $\mathbf{U}_{\mathrm{L}} \Delta \mathbf{T}_{\mathrm{g}-}$ \\
\hline 241 & 2.50 & 53.7 & 1074.2 & 1.02176 & $1.14 \times 10^{-13}$ & 22.27 & 0.0106 \\
\hline 320 & 7.74 & 150 & 2399.5 & 0.9874 & $1.44 \times 10^{-13}$ & 46.95 & 0.0233 \\
\hline 490 & 11.16 & 291 & 4244.9 & 0.9942 & $1.57 \times 10^{-13}$ & 59.48 & 0.0226 \\
\hline 770 & 19.27 & 596 & 8421.1 & 0.98582 & $1.67 \times 10^{-13}$ & 77.44 & 0.0247 \\
\hline 800 & 21.86 & 624 & 8835.6 & 0.98714 & $1.67 \times 10^{-13}$ & 78.01 & 0.027 \\
\hline 950 & 24.16 & 796 & 10840 & 0.89467 & $1.75 \times 10^{-13}$ & 83.79 & 0.025 \\
\hline 804 & 18.09 & 632 & 8838.3 & 0.98726 & $1.69 \times 10^{-13}$ & 78.66 & 0.0222 \\
\hline 765 & 19.18 & 596 & 8454.8 & 0.98769 & $1.67 \times 10^{-13}$ & 77.97 & 0.0248 \\
\hline 498 & 10.08 & 217 & 3440.7 & 0.99739 & $1.44 \times 10^{-13}$ & 43.50 & 0.0202 \\
\hline 315 & 5.10 & 85.4 & 1576.9 & 0.98963 & $1.24 \times 10^{-13}$ & 27.10 & 0.016 \\
\hline Avg. & & & & & & 59.516 & \\
\hline
\end{tabular}

Table (2) Evaluation of $\pi 1, \pi 2$ and $\pi 3$ for the control unit.

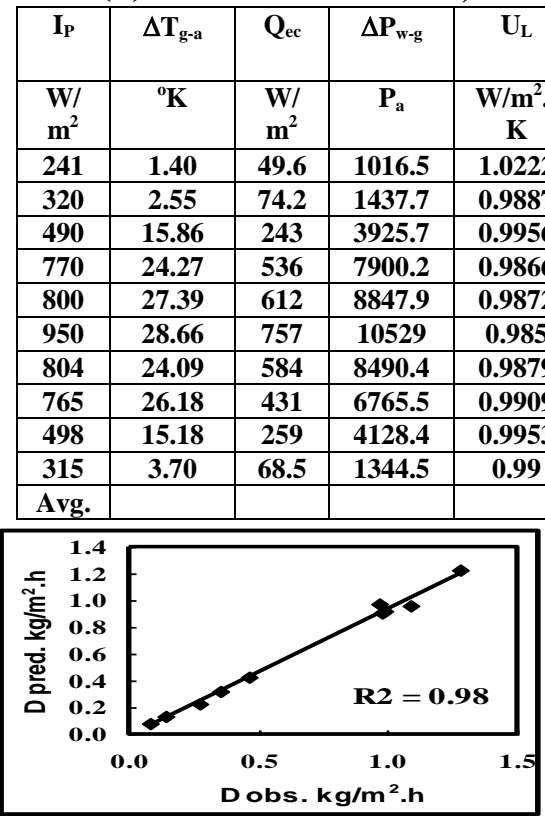

Fig(7)Predicted and observed productivity for the cooled unit

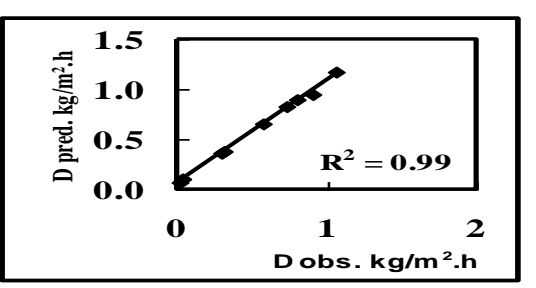

Fig(8)Predicted and observed

productivity for the control unit

The observed and predicted productivities were evaluated and correlated to each other for the two tested units, Figs.(7) and (8). Prediction equations give reliable results for the still productivity of the two studied units. The coefficients of determinations were,0.98 and 0.99 for the cooled and control units respectively.Table(3) shows that, as the solar intensity increases partial pressure potential $\Delta \mathbf{P}_{\mathbf{w}-\mathrm{g}}$, glass cover, water 
Table(3) Solar intensity, glass cover temperature $T_{g}$, brine water temperature $T_{w}$, partial pressure potential $\Delta \mathbf{P}_{\mathrm{w}-\mathrm{g}}$ and productivity for the two studied units.

\begin{tabular}{|c|c|c|c|c|c|c|c|c|}
\hline Item & \multicolumn{4}{|c|}{ Cooled unit } & \multicolumn{4}{|c|}{ Control } \\
\hline $\mathbf{I}_{\mathbf{P}}$ & $T_{g}$ & $T_{w}$ & $\Delta \mathbf{P}_{w-g}$ & D & $T_{g}$ & $\mathbf{T}_{\mathrm{w}}$ & $\Delta \mathbf{P}_{w-g}$ & D \\
\hline $\begin{array}{l}\mathbf{W} / \\
\mathbf{m}^{2}\end{array}$ & ${ }^{\circ} \mathrm{C}$ & ${ }^{\circ} \mathrm{C}$ & $\mathbf{P}_{\mathrm{a}}$ & $\begin{array}{c}\mathrm{kg} / \mathrm{m}^{2} \\
\mathrm{~h}\end{array}$ & ${ }^{\circ} \mathrm{C}$ & ${ }^{\circ} \mathrm{C}$ & $\mathbf{P}_{\mathrm{a}}$ & $\begin{array}{c}\mathbf{k g} / \mathbf{m}^{2} . \\
\mathrm{h}\end{array}$ \\
\hline 241 & 20.4 & 26 & 1074.2 & 0.0792 & 21.5 & 26.7 & 1016.5 & 0.0732 \\
\hline 320 & 22.1 & 33 & 2399.5 & 0.2232 & 27.1 & 33.1 & 1437.7 & 0.1103 \\
\hline 490 & 43 & 34 & 4244.9 & 0.4317 & 47.7 & 39 & 3925.7 & 0.3627 \\
\hline 770 & 52 & 62 & 8421.1 & 0.9125 & 57 & 65.1 & 7900.2 & 0.8222 \\
\hline 800 & 55.7 & 65 & 8835.6 & 0.9579 & 61.2 & 69 & 8847.9 & 0.9431 \\
\hline 950 & 63 & 71.8 & 10840 & 1.2304 & 67.5 & 75 & 10529 & 1.1741 \\
\hline 804 & 52.9 & 63.1 & 8838.3 & 0.9688 & 58.9 & 67 & 8490.4 & 0.8988 \\
\hline 765 & 53 & 62.8 & 8454.8 & 0.9134 & 60 & 66.4 & 6765.5 & 0.6626 \\
\hline 498 & 42.9 & 33 & 3440.7 & 0.3218 & 48 & 38.9 & 4128.4 & 0.3874 \\
\hline 315 & 25 & 32 & 1576.9 & 0.1267 & 26.4 & 32.2 & 1344.5 & 0.1017 \\
\hline Avg. & & & & 6.1655 & & & & 5.536 \\
\hline
\end{tabular}

temperatures and productivity increases. The total daily productivity and average coefficient of performance were $6.1655 \mathrm{~kg} / \mathrm{m}^{2}, 59.52 \%$ for the cooled unit compared to $5.536 \mathrm{~kg} / \mathrm{m}^{2}$ and $52.19 \%$ for the control unit. The maximum productivity, water temperature, temperature difference between water and glass cover, and partial pressure potential of 1.2304 $\mathrm{kg} / \mathrm{m}^{2} \cdot \mathrm{h}, 71.8^{\circ} \mathrm{C}, 8.8^{\circ} \mathrm{C}$, and $10840 \mathrm{P}_{\mathrm{a}}$ for the cooled unit compared to $1.0529 \mathrm{~kg} / \mathrm{m}^{2} . \mathrm{h}, 75^{\circ} \mathrm{C}, 7.5^{\circ} \mathrm{C}$ and $10529 \mathrm{P}_{\mathrm{a}}$ for the control unit.

\section{SUMMARY AND CONCLUSION}

The aim of the present study is to develop mathematical analysis for common design solar still involving all ambient surrounding variables affecting its productivity and coefficient of performance. Two similar units of the solar stills were used namely: Control unit and cooled glass cover unit (cooled unit). Similitude technique was used to develop prediction equations for these units. From the present study we can concluded that:

1- The prediction equations for the productivity of the two studied units were reasonably accepted with coefficients of determinations of 0.98 and 0.99 respectively. The predicted equations were of the form :

$$
D=\left[A\left(\frac{Q_{e c}}{I_{p}}\right)+C\right](\Phi \Delta \mathbf{p}) \frac{\cos \beta}{\lambda}
$$

Misr J. Ag. Eng., January 2010 
Where $\mathrm{D}$ is the productivity in $\mathrm{kg} / \mathrm{m}^{2} \cdot \mathrm{h}, \mathrm{C}$ and $\mathrm{A}$ are functions of $\pi 3$ or $\left[\mathrm{U}_{\mathrm{L}} \Delta \mathrm{T}_{\mathrm{g}-\mathrm{a}} / \mathrm{I}_{\mathrm{P}}\right]$ which are linearly justified,$\phi$ time duration in hours, $\mathrm{I}_{\mathrm{p}}$ solar intensity $\mathrm{W} / \mathrm{m}^{2}, \mathrm{Q}_{\mathrm{ec}}$ the heat utilized in vaporizing water in the still $\mathrm{W} / \mathrm{m}^{2}, \mathrm{U}_{\mathrm{L}}$ over-all heat loss coefficient in $\mathrm{W} / \mathrm{m}^{20} \mathrm{~K}, \mathrm{~T}_{\mathrm{g}-\mathrm{a}}$, temperature difference between ambient air and glass cover ${ }^{\circ} \mathrm{K}, \Delta \mathrm{P}_{\mathrm{w}-\mathrm{g}}$ partial pressure potential $\mathrm{kg} / \mathrm{m} . \mathrm{s}^{2}, \lambda$ is a constant represents the view factor of sky, ground and surrounding with respect to cover tilt angle.

2- It was also found that the cooled unit has highest values of the productivity and coefficient of performance. The daily productivity and average coefficient of performance were $6.1655 \mathrm{~kg} / \mathrm{m}^{2}, 59.52 \%$ for the cooled unit compared to $5.536 \mathrm{~kg} / \mathrm{m}^{2}$ and $52.19 \%$ for the control unit.

3-The maximum productivity, water temperature, temperature difference between water and glass cover, and partial pressure potential of 1.2304 $\mathrm{kg} / \mathrm{m}^{2} \cdot \mathrm{h}, 71.8^{\circ} \mathrm{C}, 8.8^{\circ} \mathrm{C}$, and $10840 \mathrm{P}_{\mathrm{a}}$ for the cooled unit compared to $1.0529 \mathrm{~kg} / \mathrm{m}^{2} . \mathrm{h}, 75{ }^{\circ} \mathrm{C}, 7.5^{\circ} \mathrm{C}$ and $10529 \mathrm{P}_{\mathrm{a}}$ for the control unit.

\section{RFERENCES}

Abdel-Rahman,G.M. 2009.Theoretical approach for using solar still to provide plant water requirement. Misr J. of Agric.Eng.,26(2):977992.

Duffie,J.A., and Wiliam,A.B.1980. Solar engineering of thermal process.Mdison.Jhon Willy and Sons, New York:85-88.

Ernani,S.1996.Solar still versus solar evaporator: A comparative study between their thermal behaviors. Solar Energy, Printed in great Britain ,56(2):199-206.

Frich,G. and J.V.Sommerfeld 1973. Solar stills of inclined evaporating cloth. Solar Energy, Printed in the USA, (4): 427-431.

Ghanem,T.H.1989. Design of a solar dryer for agricultural products. M.Sc. Th. Agric.Eng. Dept. Al-Azhar University.

Moustafa,M.E.,S.T.Ibrahim and A.S.Jaffar, 1994. Design of solar thermal systems.Sci. Publ.Center, King Abdulziz Univ. Sudia Arabia:187252.

Murphy,G.1950.Similitude in engineering . New York. The Roland press Co. : 36-37.

Rai G.D.1980. Solar energy utilization.1 st. Ed., Pub. By Romesh Chander Khanna.2-8 North market New Delhi.110006.:58-67,192196.

Misr J. Ag. Eng., January 2010 
Shoukr,A.Z., Ahmed A.E., and Sharaf G.A.1986. Prediction of temperature rise in flat plate solar collector by similitude application. Misr J. of Agric.Eng.,3(1):13-27.

Tayel,S.A.,El-Nakib, A. A.,and Badr, M.M.2009. Solar Energy utilization in water distillation. Misr J. of Agric.Eng.,26(1):428-452.

Zabady, F.I.1997. Possibility of using solar energy in irrigation. MSc. Th., Agric.Eng. Dept. Al-Azhar University.

Zaki G.M.,M.Abdulhaiy,A.Radwan and O.Balbeid . 1993. Analysis of assisted coupled solar stills.Solar Energy, Printed in great Britain, 51(4):277-288.

\section{تحليل انتاجية مقطر شمسى باستخد العبرم التحليل البعدى */د/ طارق حسين غانم}

نظر اً لندرة الميـاة العزبـة فـى بعض الأمساكن السـاحلية لجمهوريـة مصر العربية فيـة؛ بعد استخدام

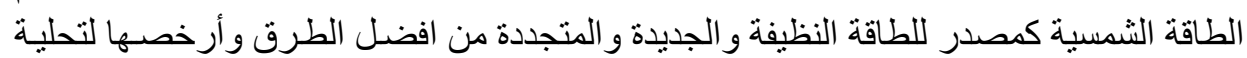

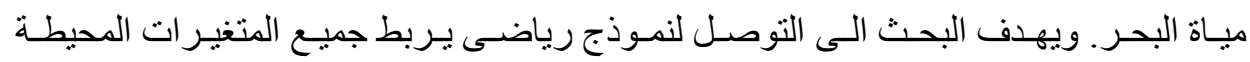

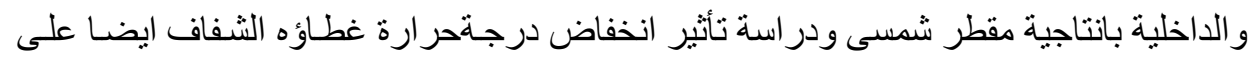

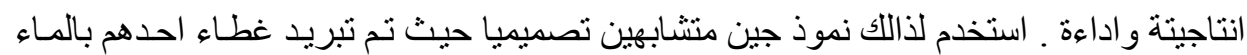

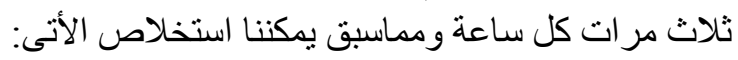

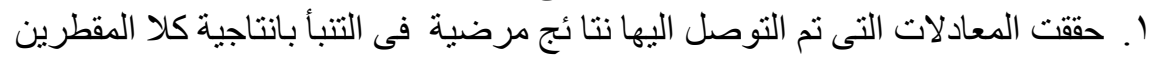

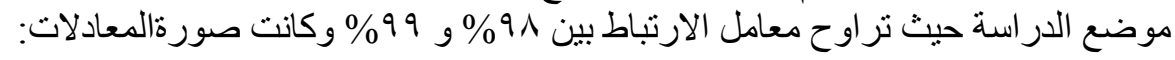

$$
\mathbf{D}=\left[A\left(\frac{\mathbf{Q}_{\mathbf{e c}}}{\mathbf{I}_{\mathbf{p}}}\right)+\mathbf{C}\right](\Phi \Delta \mathbf{p}) \frac{\cos \beta}{\lambda}
$$

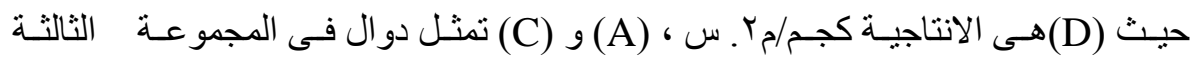

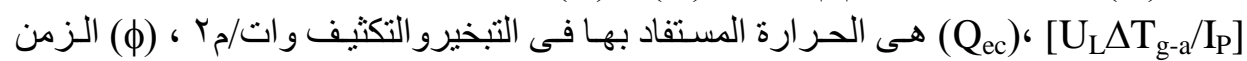

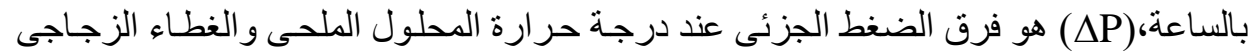

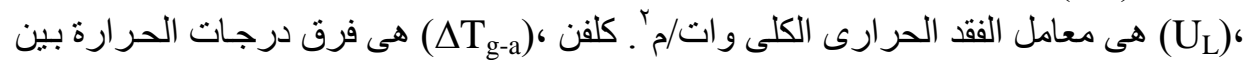

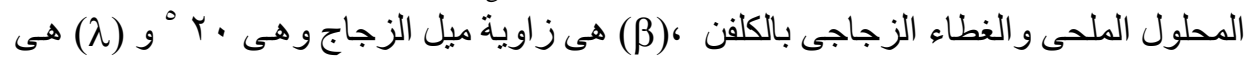
عمق المحلول فى المقطر بالمتر. r. قدرت الانتاجية اليومية ومعدل الآداء بـ

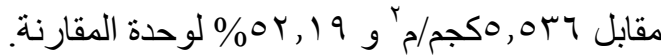

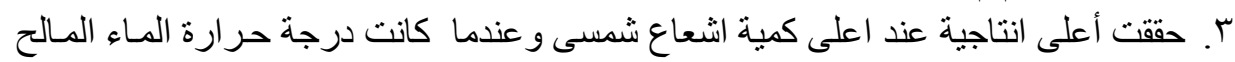

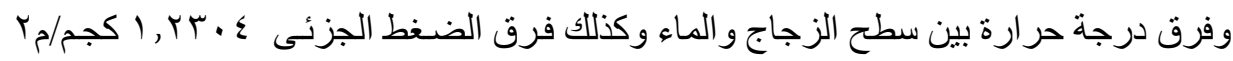

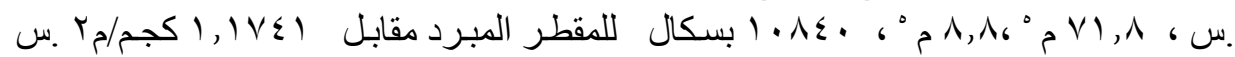

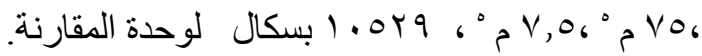

